Veli-Matti Pynttäri

\title{
Matti Kurjensaaren muotokuvat muista, muistista ja minästä
}

Kustannusosakeyhtiö Tammi julkaisi 1960-luvun puolivälissä kokoelman kirjailija Matti Kurjensaaren (1907-1988) laatimia kirjallisia muotokuvia. Veljeni merellä myrskyävällä (1966, tästä eteenpäin VMM) oli niin onnistunut kirjallinen avaus, että seuraavien viiden vuoden aikana muotokuvakokoelma täydentyi "Muotokuvia muistista” -nimiseksi trilogiaksi kokoelmien Kansakunnan kaapin päällä (1969, tästä eteenpäin KKP) ja Silmätikut (1971, tästä eteenpäin S) myötä. Kolmen alkuperäisen kokoelman lisäksi muotokuvista julkaistiin myös kaksi valikoimaa, Kulkue (1970) ja Kansalaiskirja (1970), joista jälkimmäiseen Kurjensaari oli liittänyt myös omakuvan aineksia samoihin aikoihin julkaistusta päiväkirjateoksestaan Syntynyt sivulliseksi (1973).

Jo pikainen katsaus kokoelmiin kertoo olennaisen Kurjensaaren muotokuvista. Muotokuvien kohteiksi valitut henkilöt edustavat monipuolisesti itsenäisen Suomen kulttuuri- ja yhteiskuntaelämää. Kokoelmien 62 muotokuvaa - joiden kohteena on kaiken kaikkiaan 66 henkilöä - jakautuvat lähestulkoon tasan toisaalta kulttuurin ja taiteiden, toisaalta politiikan ja talouselämän alueille. Muotokuvansa ovat saaneet niin Olavi Paavolainen, Mika Waltari ja Pentti Saarikoski kuin Pekka Kuusi, Urpo Lahtinen ja Veikko Vennamo. Kokoelmissa syntyvän historiallisen kaaren ääripäitä edustavat vanhemmasta päästä F. E. Sillanpää, Edwin Linkomies ja Vilho Helanen nuorempien Irwin Goodmanin, Jörn Donnerin ja Erkki Tuomiojan rinnalla. Vähintäänkin silmäänpistävää on myös naisten puuttuminen lähes kokonaan: ainoastaan Hella Wuolijoki ja Hertta Kuusinen ovat saaneet muotokuvansa, Wuolijoki ensimmäiseen ja Kuusinen toiseen kokoelmaan.

Muotokuvien yhteiskunnallista laaja-alaisuutta selittää suurelta osin Kurjensaaren oma aktiivinen toiminta monella kulttuurin ja yhteiskunnan alalla. Kurjensaari toimi Gummeruksen kustannustoimittajana 1930-luvulla ja osallistui kustantajan järjestämiin Suomen kulttuurin tilaa koskeviin keskusteluihin. Näiden keskustelujen pohjalta Yrjö Kivimies toimitti teoksen Pidot Tornissa (1937), jossa Kurjensaari esittää puheenvuoronsa nimimerkillä Radikaali. Lehtiuralle Kurjensaaren houkutteli K. A. Fagerholm, joka kutsui Kurjensaaren 1930-luvun puolivälissä Kansallisen edistyspuolueen perustaman Nykypäivän päätoimittajaksi. Sodan jälkeen Kurjensaari toimi Yleisradion teatteriosaston päällikkönä, kunnes palasi päätoimittajaksi, nyt SDP:n Päiväin Sanomiin. Kirjailijana Kurjensaaren ala oli laaja: 1930-luvulta lähtien hän kirjoitti muotokuvien ohella romaaneja, runoja, aforismeja, historiikkeja, esseitä ja päiväkirjoja. Aktiivinen 
yhteiskunnallinen keskustelija Kurjensaaresta tuli 1940-luvulla erityisesti teoksessa Taistelu huomispäivästä: isänmaan opissa 1918-1948 (1948), jossa asemoitiin itsenäisen Suomen isänmaallisuutta sotien jälkeiseen uudenlaiseen maailmaan.

Toinen Kurjensaaren muotokuville ominainen piirre näkyy hyvin vuonna 1978 julkaistuun valikoitujen muotokuvien kokoelmaan Kansalaiskirjaan liitetyssä Kurjensaaren omakuvassa. Kansalaiskirjaan keskeiselle paikalle sijoitettu jakso "Minä" kuvaa Kurjensaaren kirjoittavaa minää, joka nousee näkyvästi esille myös muita kuin Kurjensaarta itseään kuvaavissa muotokuvissa. ”Minässä” näkyy hyvin myös Kurjensaaren muotokuville tyypillinen kietoutuminen Kurjensaaren oman henkilön ympärille - kirjoittaessaan muista Kurjensaari kirjoittaa aina myös itsestään.

Kurjensaaren muotokuvien nimittäminen esseiksi - tarkemmin muotokuva- tai henkilöesseiksi - on aina tulkintaa, kuten lajimääreitä koskevat käsitykset lähes poikkeuksetta ovat. Esseen kohdalla lajimääritelmän suhteellisuutta korostaa alalajien runsaus: esseen lajin suojissa kukoistavat esimerkiksi matkaessee, kirjallisuusessee, tieteellinen essee ja henkilökohtainen essee (personal essay) puhumattakaan lähilajeista, kuten pakinasta tai artikkelista. Kurjensaaren muotokuvaesseet liittyvät tällaisessa maastossa läheisesti esimerkiksi kirjallisuusesseistiikkaan ja kirjailijamuotokuviin, joilla on suomalaisessa esseekirjallisuudessa pitkät perinteet, mutta myös esimerkiksi niin sanottujen luonnekuvien perinteeseen. 1600-luvun Ranskassa kukoistaneessa esseetyypissä, jonka kuuluisimpana edustajana on pidetty Jean de La Bruyèren (1645-1696) teosta Les caractères ou les moeurs de ce siècle (1688), oli tavanomaista esittää huomioita sekä erilaisista ihmistyypeistä että aikakauden tavoista ja seuraelämästä (Riikonen 1990, 57-58). Kurjensaaren pistävät huomiot ovat usein tällaisia välähdyksenomaisia luonnehdintoja aikalaisista, mutta luonnekuvista poiketen Kurjensaaren muotokuvat pyrkivät juurruttamaan kohdehenkilönsä heidän historiallisiin ja yhteiskunnallisiin yhteyksiinsä. Kevyitä muotokuvat eivät ole, ne kantavat aina mukanaan kohdehenkilöidensä historiallista painolastia.

Tässä artikkelissa tarkastelen Kurjensaaren muotokuvia esseinä kiinnittämällä ensin huomiota aikalaisvastaanottoon, jossa oli nähtävissä kahdenlaisia mielipiteitä koskien muotokuvien "oikeaa" lukutapaa ja siten lajimääritelmää. Tämän jälkeen nostan esille Kurjensaaren tavan kirjoittaa itsensä osaksi muotokuvia, mikä häivyttää esseiden kohteen ja niiden kirjoittajan välistä rajaa. Lisäksi huomioin muotokuvien likeisen suhteen historiaan ja yhteiskunnalliseen todellisuuteen. Nämä piirteet tekevät muotokuvista Kurjensaaren oman näkemyksen mukaan esseitä.

\section{Muotokuvaesseet Suomessa}

Aikalaisvastaanotossa Kurjensaaren muotokuvat saivat osakseen kiitosta. Helsingin Sanomien Pekka Tarkka ja Hufvudstadsbladetin J. O. Tallqvist korostivat arvosteluissaan Kurjensaaren liittymistä pitkään esseekirjallisuuden perinteeseen. Tallqvist (1967) koros- 
taa, että essee on taidemuoto ja että Kurjensaari hallitsee lajinsa "loistavin tuloksin". Näkemys ei muutu myöhempienkään kokoelmien kohdalla, sillä Tallqvist (1971) tuo esille trilogian päätösosan jälkeen, että Kurjensaari hallitsee muotokuvaesseen suvereenilla tavalla ilman kotimaista vastinetta. Tarkka (1971) puolestaan yhdistää Kurjensaaren muotokuvaesseen renessanssista periytyvään kirjalliseen traditioon ja sen jälkeen tuleviin ranskalaiseen ja brittiläiseen suuntaukseen. Hän kuitenkin kiittää Kurjensaarta siitä, että tämä sitoutuu muotokuvissa aikaan ja paikkaan, toisin kuin historialliset edeltäjänsä.

Vaikka Tallqvist katsookin arvostelussaan, ettei muotokuvilla ole suomenkielisessä kirjallisuushistoriassa edeltäjää, niin vertailukohtia on kuitenkin mahdollista löytää. Suomen kirjallisuushistoriassa Kurjensaaren muotokuvien voi katsoa sijoittuvan pitkään kirjailijoihin keskittyvään muotokuvaesseen perinteeseen, jonka Tarkka (1970, 251-252) mainitsee omana juonteenaan suomalaisen esseen historiassa. Kurjensaaren muotokuvat asettuvatkin kirjailijaesseiden jatkumoon, joka alkoi Eino Leinon kokoelmalla Suomalaisia kirjailijoita (1909) ja Anna-Maria Tallgrénin kokoelmalla Runoilijoita (1910) ja jota vuosisadan alkukymmenillä jatkoi myös V. A. Koskenniemi Roomalaisia runoilijoita -kokoelmalla (1919). Toisin kuin edeltäjänsä, Kurjensaari ei rajoittanut muotokuviaan kirjailijoihin vaan päinvastoin vähensi kirjailijamuotokuvien määrää huomattavasti kohti Silmätikkuja. Yhtäläisyyksiä voi silti nähdä etenkin siinä, minkälaisena kirjoittamisen muotona muotokuva käsitettiin. Kun Kurjensaari luonnehtii Veljeni merellä myrskyävällä -kokoelman esipuheessa muotokuviaan varjokuviksi, analyyseiksi ja pikapiirroksiksi (VMM, 6), niin hän näyttää toistavan Leinon kokoelmalleen antamaa alaotsikkoa "pikapiirroksia" ja olevan myös erittäin lähellä Tallgrénin käyttämää "luonnekuvia"-luonnehdintaa.

Muotokuvaesseen renessanssissa Kurjensaari ei kuitenkaan ollut yksin. Muutama vuosi "Muotokuvia muistista" -sarjan ilmestymisen jälkeen myös Arvi Kivimaa kirjoitti muotokuvien sarjan, jonka ensimmäisen osan nimi Kasvoja valohämyssä (1974) toimi seuraavien osien Ystäviä (1977) ja Ihmisen rohkeus (1978) alaotsikkona (ks. myös Riikonen 1990, 105). Verrattuna Kurjensaareen Kivimaan muotokuvat keskittyvät enemmän kirjailijoihin ja jättävät yhteiskunnallisen alueen vähemmälle huomiolle.

Hakeutuessaan aihevalinnoissa kulttuurisesti yhä laajemmalle alueelle Kurjensaari oli siten myös uudistamassa suomalaisen muotokuva- ja henkilöesseen perinnettä. Siinä missä suomenkielinen esseekirjallisuus oli pitkälti keskittynyt kirjallisiin aiheisiin, kirjailijoihin ja heidän teoksiinsa (Korhonen 2013, 311), laajensi Kurjensaari muotokuvillaan aihealuetta kirjallisuuden ulkopuolelle ja oli siten myös muuttamassa esseen lajin asemaa yhteiskunnallisessa keskustelussa. Huomiota herättävää on kuitenkin se, että avautuessaan uusille yhteiskunnan alueille Kurjensaari jätti naiset edelleen muotokuviensa ulkopuolelle. Tässä suhteessa ensimmäisen kokoelman nimi Veljeni merellä myrskyävällä on otettava kirjaimellisesti, sillä "veljien” joukkoon mahtui vain 
yksi nainen, Hella Wuolijoki. Wuolijoen lisäksi ainoa nainen on Kansakunnan kaapin päällä -kokoelmaan muotokuvansa saanut Hertta Kuusinen. Naisilla ei tässä mielessä ollut oikein paikkaa Kurjensaaren maalaamassa kuvassa suomalaisesta yhteiskunnasta ja kulttuurista.

Suuntautuminen pois kirjallisuuden henkilöistä, muotokuvien kiinnittyminen läheisesti aikaan ja paikkaan ja Kurjensaaren usein varsin tuttavallinen ja välitön suhtautuminen muotokuvien kohdehenkilöihin aiheutti myös epätietoisuutta Kurjensaaren muotokuvien paikasta kirjallisuuden lajien keskuudessa tai niiden ulkopuolella. Monille kriitikoille nämä piirteet näyttäytyivät ominaisuuksina, jotka yhdistivät Kurjensaaren muotokuvat kirjallisuuden sijasta journalismiin. Esimerkiksi Kai Laitinen (1967) lähestyy Kurjensaaren muotokuvien ambivalenttia luonnetta kaunokirjallisuuden ja asiaproosan välimaastossa hyväksyvästi ja luonnehtii Kurjensaarta kirjailijana lehtimieheksi ja lehtimiehenä kirjailijaksi. Samaa näkemystä edustaa Helsingin Sanomien Marja Niiniluoto (1969), joka katsoo muotokuvien edustavan jalostettua versiota "aikamme vitsauksesta, popparireportaasista”.

Jyrkemmin samaan kysymykseen suhtautui esimerkiksi Kalevan Aku-Kimmo Ripatti (1971), joka katsoi muotokuvien olevan "aikakauslehtitasoa" ja kuuluvan siksi paremmin Urpo Lahtisen Hymyyn. Etenkin Ripatin näkemyksessä käsitys Kurjensaaren muotokuvien alhaisesta tasosta on sidoksissa hänen käsitykseensä siitä, minkälaisesta kirjoittamisen lajista muotokuvissa on kyse. Muotokuvien liittäminen esseekirjallisuuden perinteeseen näyttāä olleen yhteydessä myönteiseen suhtautumiseen ja vastaavasti tämän yhteyden ohittaminen on antanut arvostelijoille useammin syytä esittää negatiivisia huomioita muotokuvien kevyestä luonteesta. Toisille (Tarkka, Tallqvist) Kurjensaaren paikka oli pitkässä kirjallisuushistoriallisessa jatkumossa, kun taas toisille (Ripatti) muotokuvien tuttavallisuus ja eräänlainen arkipäiväisyys merkitsivät kirjallisuuden alennustilaa ja ajautumista kohti lehtikirjoittelua.

Erityisesti Kurjensaaren liikkuminen Suomessa perinteisesti kirjailijoihin keskittyneen muotokuvaesseistiikan laitamilta kohti laajempaa kulttuurielämää on tulkittavissa myös osoitukseksi kirjallisuuden muuttuneesta asemasta kulttuurin kentällä ja julkisuuden sfäärin muutoksista 1960- ja 1970-lukujen taitteessa. Kurjensaari tuntuukin tavoittaneen muotokuvillaan jotakin ajan hengen mukaista. Tähän kiinnitti huomiota myös Tarkka arvioidessaan Kurjensaaren uutta muotoa. Tarkka (1971) kirjoittaa Kurjensaaren muotokuvien - "henkilöesseiden" - olevan myönnytys "tavalliselle ihmiselle, pikkuporvarille", sillä Kurjensaarelta ei hänen mukaansa ole jäänyt huomaamatta "tämän hetken julkisuuden henkilökeskeisyys". Vaikka Tarkka muuten arvostelussaan korostaakin Kurjensaaren muotokuvien kirjallisuus- ja lajihistoriallisia yhteyksiä esseen perinteeseen, niin hän tunnistaa myös henkilökeskeisyyden vetovoiman ajan julkisuudessa. Tähän vetovoimaan Kurjensaari pystyi kiinnittymään muotokuvillaan. 


\section{Minä keskellä muotokuvaa}

Ääriviivoiltaan kolmen kokoelman muotokuvat noudattavat pitkälti samaa mallia. Kurjensaari aloittaa muotokuvansa usein kohdehenkilöä koskevalla anekdootilla tai historiallisella yksityiskohdalla. Esimerkiksi muotokuvan Olavi Paavolaisesta - josta Kurjensaari kirjoitti myöhemmin kokonaisen teoksen Loistava Olavi Paavolainen (1975) - Kurjensaari aloittaa päivämäärällä, jolloin Paavolaisten kotitalo Kivennavalla poltettiin maan tasalle talvisodan ensimmäisinä tunteina (VMM, 70). Ralph Enckellin muotokuva alkaa puolestaan kuvauksella Nyrki Tapiovaaran ohjaamasta elokuvasta Varastettu kuolema (1938), jossa Enckell esiintyy nimellä Ilmari Mänty. Osuvalla tavalla Kurjensaari asettaa rinnakkain nuoren Enckellin elokuvatähtenä ja kansainvälisen uran tehneen vanhemman diplomaatin ja toteaa: "Yhtä kauan kuin filmitähti Ilmari Mänty on ollut sammuneena, yhtä kauan on diplomatian taivaalla loistanut Ralph Enckell. He olivat yksi ja sama henkilö.” (VMM, 153-154.) Toisissa muotokuvissa Kurjensaari taas tuo aloituksissa esille kulttuurihistoriallisen kokemuksensa, kuten esimerkiksi muotokuvassa T. Vaaskivestä. Kurjensaari aloittaa tämän muotokuvan laajalla katsauksella 1930-luvun kulttuuripoliittisiin rintamalinjoihin ja vasta tämän jälkeen edes mainitsee Vaaskiven ja kohdistaa katseensa tähän (VMM, 95-97).

Kurjensaari näkee jokaisessa muotokuvassa paljon vaivaa kuvatessaan kohdehenkilöiden historiaa ja perhetaustaa, joskus jopa muutaman sukupolven taakse. Paljon huomiota muotokuvissa saa poliittisten ja yhteiskunnallisten jakolinjojen selvittäminen ja erityisesti vuoden 1918 sisällissodan merkitys, jonka vaikutuksen pysyvyyttä Kurjensaari toistuvasti korostaa. Muotokuvissa ihminen on ennen kaikkea yhteiskunnallinen olio, jolle poliittisten jakolinjojen ylittäminen vaatii tietoista ponnistelua. Vaikka muotokuviin mahtuu monenlaisia ihmiskohtaloita, niin yhteistä on näiden kohtaloiden ymmärtäminen osana yhteiskunnan kehitystä.

Yhteistä muotokuville on myös Kurjensaaren oma näkyvyys. Kirjoittajana Kurjensaari ei häivytä itseään taka-alalle tai täysin näkymättömiin vaan pikemminkin korostaa omaa rooliaan muotokuvien kirjoittajana. Kuvaava osoitus tästä on kirjallisuusarkistossa säilynyt, vuoden 1947 alkuun päivätty suunnitelma, jossa Kurjensaari on hahmotellut kirjaideaa otsikolla "Muotokuvia sanan siveltimellä". Sisällöllisesti suunnitelma ei kerro paljoakaan kahden vuosikymmenen jälkeen julkaistuista muotokuvakokoelmista, mutta se sisältää kuvaavan hahmotelman suunnitellun kokoelman kansikuvaksi: Kurjensaari luonnosteli itsestään verrattain tarkkaa kansikuvaa maalarintakkiin pukeutuneena ja maalaustelineen ääressä. Ero on suuri verrattuna julkaistun Veljeni merellä myrskyävällä -kokoelman kanteen, jossa on muotokuvien kohdehenkilöiden valokuvia. Kun vielä suunnitelmissa Kurjensaari korosti omaa rooliaan kirjailijana, muotokuvien maalarina, niin julkaistuissa teoksissa kansikuviin nostettiin muotokuvien kohteet. Teosten visuaa- 
lisessa ilmeessä kokoelmat esiteltiinkin muotokuvien kohteiden eikä niiden kirjoittajan kautta. Kurjensaaren varhaisiin suunnitelmiin nähden asetelma kääntyi päälaelleen. (Kirjallisuusarkisto, Matti Kurjensaaren arkisto kansio nro 6, kotelo 29440.)

Kurjensaaren fantasiaa itsestään muotokuvamaalarina ei tule tulkita yksinomaan osoituksena Kurjensaaren omasta näkymisen halusta tai esseen lajiin laajemmin liitetystä itsekeskeisyydestä (esim. Sanders 1991, 197). Enemmänkin kyse on kuvaajan ja kuvattavan välillä vallitsevan suhteen vastavuoroisuuden tunnustamisesta. Silmätikkujen alkulauseessa Kurjensaari kirjoittaa: "[M]allin ja kirjoittajan välillä käy näkymätön sähinä. [- - Jokainen malli on kehittänyt kuvaajaansa ja olen siitä heille kiitollinen.” (S, 7.) Yhtä lailla jo ensimmäisen kokoelman esipuheessa Kurjensaari arvelee, ettei tekijä - hän itse - "ole riittävän selväpiirteinen fysikaalinen kappale, vaan hänessä on kemiallisen liuoksen ominaisuuksia" (VMM, 6). Tämä vastavuoroisuus ja rajojen hälveneminen kuvaajan (subjektin) ja kuvattavan (objekti) väliltä on Kurjensaarelle muotokuvien kirjoittamisen olennainen osa: muotokuvassa sekoittuvat näkemykset kohteesta, kirjoittajasta ja muistamisesta.

Esseetutkija Graham Good (1988, 21-22) onkin korostanut esseen kirjoittajan ja kuvauksen kohteen vastavuoroisuuden merkitystä esseelle ominaisena tietämisen tapana ja erityisen esteettisen tiedon muotona. Siinä missä Kurjensaaren muotokuvaesseiden kohteena on henkilö, laajentaa Good muotokuvan kattamaan myös muunlaisia kuvauksen kohteita maisemista taideteoksiin. Goodin (1998, 21-22) mukaan esseemuodon ytimessä on prosessi, jossa esseen subjekti tunnistaa ja löytää kuvauksensa kohteesta jotain, joka kertoo samalla jotain esseististä itsestään. Vastavuoroisesti kuvauksen kohde saa ilmaisunsa vain kuvaajassa. Ennen kaikkea kyse on käsityksestä, jossa essee nähdään kirjoitusmuotona, joka kyseenalaistaa erillisten subjektiivisen ja objektiivisen tiedonmuodostuksen alueiden olemassaolon (Good 1988, 130). Kurjensaarelle muotokuvaesseiden kirjoittaminen suomalaisen kulttuurin ja yhteiskunnan näkyvistä henkilöistä on aina samalla oman itsensä peilaamista saman kulttuurin ja yhteiskunnan kehitykseen.

Kurjensaaren henkilökohtaista suhdetta muotokuviensa kohteisiin kuvastaa hyvin kolmessa kokoelmassa toistuva alaotsikko "Muotokuvia muistista", jonka myötä Kurjensaari sisäistää kuvauksensa kohteet itseensä ja tekee itsestään, omasta muistamisestaan, esseiden todellisen aiheen.

Muotokuvien näkyvä piirre lähes jokaisessa esseessä on Kurjensaaren oma peittelemätön läsnäolo kuvaamiensa kohteiden rinnalla. Koska kyse on esseistä, on teksteiltä syytäkin odottaa subjektiivista otetta aiheen käsittelyyn, mutta tätäkin taustaa vasten Kurjensaari tuo itsensä poikkeuksellisen vahvasti osaksi muotokuvia. Esimerkiksi kirjoittaessaan Hertta Kuusisen muotokuvaa esseessä "Hertta vain” Kurjensaari aloittaa tekstin lyhyellä tarinalla tai anekdootilla. 
Ajoin yömyöhällä ravintolasta, jätin tuttavan Temppelikadulle ja jatkoin matkaa. Kysyin taksinkuljettajalta:

- Tunsitteko tuota äskeistä herraa?

- En.

- Se oli entinen sisäministeri Yrjö Leino.

Monta vuotta myöhemmin ajoin Albertinkadulta Arkadianmäelle ja jätin erään kansanedustajan Töölön graniittipalatsin vierustalle. Kysyin taksimieheltä:

- Tunsitteko tuota äskeistä daamia?

- Kyllä vain, sehän oli Hertta Kuusinen. (KKP, 43.)

Hertta Kuusisen muotokuvaa ajatellen tämän lyhyen, omaksi kappaleekseen erotetun tarinan tarkoitus on johdattaa lukija havaitsemaan ennalta kaksi asiaa, jotka kehystävät loppuesseessä Kurjensaaren kohteestaan kirjoittamaa kuvaa. Kurjensaari nostaa anekdootilla lukijan silmien eteen ensinnäkin Kuusisen avioliiton Yrjö Leinon kanssa - jossa "mies oli tämän avioliiton heikompi astia" (KKP, 44) - ja toiseksi Kuusisen julkisen näkyvyyden sekä aktiivisena poliittisena toimijana että ristiriitoja herättäneen Otto Wille Kuusisen tyttärenä. Esseen jatkossa nämä kaksi näkökulmaa kietoutuvat toisiinsa, mutta aloituksessa silmäänpistävää on tapa, jolla Kurjensaari vaivattomasti sijoittaa muiston omasta elämästään osaksi Kuusisen muotokuvaa.

Tyypillistä muotokuvissa on myös tapa, jolla Kurjensaari kirjoittaa muistonsa näkyviin. Käyttäessään dialogia Hertta Kuusisen ja esimerkiksi valtakunnansovittelija Keijo Liinamaan muotokuvassa Kurjensaari asettaa itsensä sekä muistelijan - muiston subjektin - että puhujan paikalle.

Erosin Keijo Liinamaasta Mannerheimintiellä ja valtakunnansovittelija jatkoi postitalon ohi kotiinsa Vuosaareen. Auton penkillä makasi salkku, joka sisälsi tavanmukaista kotityötä virkapöydältä. Kaupunki oli hiljenemässä ja painuva aurinko valaisi viileätä kesäiltaa.

- Tuliko tehtyä, kysyin aamulla.

- Eipä tullut, tuskin olin päässyt ovesta, kun puhelin soi ja minut hälytettiin takaisin kaupunkiin. (KKP, 233.)

Asettaessaan itsensä dialogin osapuoleksi Kurjensaari ei halua yksinomaan välittää muistojaan tai anekdootteja osaksi muotokuvaa, vaan hän haluaa ikään kuin korostaa myös omaa läsnäoloaan kuvaamissaan historiallisissa tapahtumissa. Muotokuvaesseiden kertojasta tulee näin myös kokija.

Yhdenlaisesta osallisuudesta ja näkyvyydestä on kyse myös Kurjensaaren käyttämissä retorisissa tehokeinoissa. Kirjoittamalla muotokuviin toistolle perustuvia rakenteita hän kiinnittää huomiota omaan toimintaansa muotokuvien rakentajana. Näkyvintä tämä toisteisuus on esimerkiksi Yrjö Jylhän ja Arvo Turtiaisen muotokuvissa. Kurjensaari aloittaa Jylhän muotokuvan "Runoilija ja konepistooli" jälleen omakohtaisiin kokemuksiin perustuvalla muistikuvalla: "Kesällä 1925 ilmestyi Hämeenlinnan kaupunginkirjaston kävijäluetteloon muuan nimi, joka herätti heti vilkasta mielenkiintoa 
niiden paikallisten nuorukaisten keskuudessa, jotka lukivat 'Nuorta Voimaa' ja seurasivat uutta kirjallisuutta" (VMM, 38). Kyse on aloittelevasta runoilijasta Yrjö Jylhästä, joka sähköisti Hämeenlinnan kirjallista elämää toimimalla kesän 1925 maanmittaajana. Nuoruuden muistoistaan Kurjensaari siirtyy käsittelemään Jylhän uraa runoilijana ja otsikon mukaisesti myös tämän toimintaa talvisodassa. Mielenkiintoista on kuitenkin myös se, kuinka Kurjensaari rytmittää esseetään viittaamalla uudelleen esseen puolivälissä alussa esittämäänsä muistoon: "Kuusitoista vuotta oli kulunut siitä rauhan kesästä, jolloin Yrjö Jylhä koulupoikien avustamana ja kiinteästi seuraamana kartoitti maalauksellisen Hämeenlinnan katuja ja pihoja” (VMM, 44). Muistikuva Jylhästä Hämeenlinnassa rakentaa muotokuvasta spiraalimaisen kokonaisuuden, joka muiston myötä alkaa ikään kuin uudelleen.

Päiväkirjamerkinnät, muistiinpanot ja kirjailijahaastattelut antavat myös toisenlaisen näkökulman Kurjensaaren läsnäoloon esseissään. Esimerkiksi kirjailijahaastattelussa vuodelta 1974 Kurjensaari toteaa halunneensa kirjoittaa muotokuvaesseitä valtaapitävistä, koska häneltä itseltään puuttui vallanhalu ja poliittinen kyky. Siitä huolimatta hän halusi vierailla vallan maailmoissa. (Kian 1986044a.) 1940-luvulle sijoittuneessa muistiinpanossa Kurjensaari taas erittelee oman luonteensa jakautumista toisaalta elämäniloiseen puoleen ja toisaalta viileän tarkkailijan rooliin. Yhteistä näille kummallekin on kuitenkin "tahto valtaan, ei korkeimmalle, vaan toiseksi tai kolmanneksi mieheksi" (kansio 8, kl 29442-29443). Saman ambivalenssin ilmentymänä voi pitää muotokuvaesseissä näkyvää oman läsnäolon kirjoittamista muotokuvien kohteiden liepeille. Tummanpuhuvan ilmauksen sama asia saa Kurjensaaren päiväkirjamerkinnässä 22.2.1972, jolloin hän kuvailee muotokuvien kirjoittamista itsemurhan myönteisenä lajina (Kurjensaari 1973, 284-285). Poispyyhitty läsnäolo ja siitä jääneet merkit ovat Kurjensaaren sosiaalisen olemassaolon ja muotokuvien kirjoittamisen kulmakiviä.

\section{Muotokuvien yhteiskunnallisuus ja esseiden argumentoivuus}

Tekijän läsnäolo - hänen kirjoittautumisensa muotokuvien kohteiden rinnalle - on yksi näkyvä ominaisuus, joka liittää muotokuvat kirjoitusmuotona esseen lajityyppiin sellaisena kuin esimerkiksi Graham Good (1988, 21-22) esseen ymmärtää. Rajan liukeneminen esseen kohteen ja esseen kirjoittajan välillä on esseessä poikkeuksellisen näkyvää, mikä on aiheuttanut myös syytöksiä lajin itsekeskeisestä luonteesta (esim. Sanders 1991, 197). Myöskään Kurjensaaren kohdalla tunnetta ei voi välttää, mutta tästä tuskin voi arvostella muistikuvistaan ammentavaa kirjoittajaa.

Lajina essee ei kuitenkaan lepää yksinomaan kirjailijan henkilökohtaisuuden varassa, vaikka muiden kiinnekohtien löytymisestä esseetutkimuksessa ollaankin erimielisiä. Esseen lajin kohdalla puhutaankin usein hybridimäisyydestä, taipumattomuudesta selkeisiin määritelmiin. Niin syvälle esseen olemukseen lajimääreiden vastustuksen 
on katsottu menevän, että sitä on pidetty anti-genrenä, lajimääreitä ylipäätään kaihtavana kirjoitusmuotona (esim. Korhonen 1998, 13). Ainoana esseen lajia yhdistävänä piirteenä onkin nähty lajin märittelemättömyys (Obaldia 1995, 2). Samaa geneeristä epätäsmällisyyttä ja ylirajaisuutta myös Kurjensaari korostaa omien muotokuvaesseidensä yhteydessä. Veljeni merellä myrskyävällä -kokoelman (1966) alkulauseessa hän toteaa kuvauksen näkökulman ja käsittelytavan vaihtelevan kokoelman teksteissä: "[- - on esseitä, varjokuvia, analyysejä, pikapiirroksia" (VMM, 6). Toisaalta esimerkiksi Savon Sanomien haastattelussa hän korostaa Kansakunnan kaapin päällä-teoksen olevan esseekokoelma, ei seurapiirikuvaus tai elämäkertateos, mikä viittaa verrattain selvään käsitykseen esseiden olemuksesta verrattuna haastattelijan ehdottamiin kirjoittamisen muotoihin (Kantola 1969).

Samassa haastattelussa Kurjensaari pitää kiinni muotokuviensa laajemmasta yhteiskunnallisiin ja historiallisiin kysymyksiin suuntautuvasta motiivista. Hän toteaa, ettei yksikään kokoelman sivuilla kuvattu henkilö edusta ainoastaan itseään, vaan jokainen heistä on henkilö "ajan draamassa" (Kantola 1969). Tässä mielessä yksittäiset henkilökuvat muuttuvat yleisiä yhteiskunnallisia ja kulttuurisia merkityksiä hakeviksi esseiksi. Kurjensaarelle muotokuvien esseemäisyys ilmenee niiden tavassa kiinnittyä laajempaan kulttuuriseen ja yhteiskunnalliseen näkökulmaan. Kysymys muotokuvien lajista koskee enemmän tekstin toimintaa historiallisessa ja yhteiskunnallisessa kontekstissa eikä niinkään kirjallisten ja tekstuaalisten ominaisuuksien määrittelyä.

Esseen poliittisuutta kartoittavan kirjoituskokoelman Politics of the Essay (1993) johdannossa kokoelman toimittajat Ruth Ellen Boetcher-Joeres ja Elizabeth Mittman (1993, 16-17) hakevat esseen määritelmää ajattelemalla sitä väitteenä: heidän mukaansa esseelajin ytimessä on sen osia yhdistävä argumentti. Essee puhuu asiansa puolesta, se ei ainoastaan esitä todisteita vaan myös esittää tulkinnan. Samanlaisen esseekäsityksen puolesta puhuu myös Scott Russell Sanders (1991, 202-203), joka katsoo esseistin puhuvan aina todellisesta maailmasta. Esseistin erottaa kaunokirjailijasta hänen suhtautumisensa aiheeseensa, hänen vilpitön halunsa kirjoittaa näkemästään maailmasta. Kummatkin käsitykset välittävät näkemystä esseestä "poliittisena" lajina - tosin ei niin, että ratkaisevassa asemassa olisivat esseiden ja argumenttien sisällöt vaan ennen kaikkea halu kirjoittaa esseet kannanottoina maailmaan, historiaan ja yhteiskuntaan.

Jos Kurjensaaren muotokuvia lähestyy tällaisena argumentaationa, niin huomiota kiinnittää Kurjensaaren tapa rakentaa muotokuvansa vastakkainasettelujen - dikotomioiden - varaan. Esipuheessa Veljeni merellä myrskyävällä -kokoelmaan (1966) Kurjensaari toteaa, että muotokuvien kirjoittamista ohjaa näkemys, jonka mukaan "jokaisessa ihmisessä on ainakin kaksi eri puolta, julkinen maine ja sisäinen todellisuus. Usein ne vaikuttavat ristikkäin; julkinen maine hautaa sisäisen todellisuuden ja päinvastoin.” (VMM, 6.) Usein Kurjensaari on kirjoittanut muotokuvan ristikkäisyyden näkyville 
ainakin vertauskuvallisesti jo esseiden otsikoihin: esimerkiksi muotokuva Yrjö Jylhästä on otsikoitu "Runoilija ja konepistooli", Ilmari Turjaa kuvastaa hyvin "Kulosaaren talonpoika" ja Mauno Koiviston tausta kiteytyy otsikossa "Telakka ja pankki". Muotokuvien kohteina olevien henkilöiden esittäminen pitkässä henkilö- ja yhteiskuntahistoriallisessa yhteydessä, yhteiskunnallista vastakkainasettelua ja eräänlaista ristivalotusta korostavan näkökulman omaksuminen historiallisten yhteyksien pohjalta ja viimein yhteiskunnallista konsensusta ja poliittista kompromissikykyä osoittavan johtopäätöksen esittäminen Kurjensaaren omissa nimissä muodostavat kokoelmien muotokuvaesseiden tärkeimmät kiinnekohdat.

Kaikkiaan neljässä esseessä Kurjensaari on ottanut kohteekseen yhden sijasta kaksi henkilöä. Kurjensaaren valitsemat parit - Uuno Laakso ja Aku Korhonen, Jarno Pennanen ja Matti Kuusi, Väinö Leskinen ja Aarre Simonen, sekä Martti Paloheimo ja Toivo Pihkanen - edustavat usein keskenään yhteiskunnallisesti vastakkaisia ihmistyyppejä, joiden vertailu suo Kurjensaarelle mahdollisuuden rakentaa historiallisesti pitkiä kaaria suomalaiseen yhteis- ja kansakuntaan. Esimerkiksi Silmätikuissa esiteltyjen psykiatrien Martti Paloheimon ja Toivo Pihkasen mahduttamisesta samaan esseeseen Kurjensaari toteaa: "Se mikä näitä kahta läkäriä yhdistää ja erottaa, on oman aikamme vahvaa historiaa" (S, 172). Historialla Kurjensaari tarkoittaa ennen kaikkea kohteittensa henkilöhistorian vaiheita, mutta hän korostaa näiden vaiheiden liittymistä Suomen historian käänteisiin sekä kohdehenkilöiden itsensä että heitä edeltävien sukupolvien elämässä. Yhteiskunnan historia ja siihen liittyvät poliittiset jakolinjat eivät ole Kurjensaarelle vain taustalla vaikuttavia tosiasioita, vaan ne muodostavat myös muotokuvien tulkintakehyksen. Näin tapahtuu esimerkiksi Paloheimon ja Pihkasen muotokuvassa:

Jos Martti Paloheimo on synnynnäinen oikeistolainen, joka omilta taipumuksiltaan on sosiaalidemokraatti ja liberaali, Toivo Pihkanen on synnynnäinen vasemmistolainen, joka omilta taipumuksiltaan on sosiaalidemokraatti ja liberaali. Puolueilmaisuja käytetään tässä vertauskuvallisesti, mielenlaadun osoituksena. $(S, 185$.

Omimmillaan Kurjensaari on luodessaan muotokuviin vastakkainasetteluja kohteiden yhteiskunnallisen, poliittisen ja historiallisen taustan perusteella, vaikka hän lopulta osoittaakin näiden jaottelujen riittämättömyyden omassa kompromisseihin, tasapainoon ja konsensukseen tähtäävässä näkökulmassaan. Tässä suhteessa Kurjensaarella on (henkilö)historioitsijana käsissään loputon todistusaineisto suomalaisen yhteiskunnan jakaantumisesta sisällissodan jälkeen punaisiin ja valkoisiin - Kurjensaarelle itselleenkin hyvin traumaattinen jakolinja - mutta poliittisena idealistina hän pyrkii löytämään materiaalistaan syyn ja aiheen kompromissille, poliittiselle synteesille, puoli vuosisataa sisällissodan jälkeen. 
Muotokuvista voi tuskin löytää osuvampaa kuvausta Kurjensaaren poliittisesta halusta konsensukseen ja vakauteen kuin Silmätikut päättävä Aarne Saarisen muotokuvan lopetus. "Maassa maan tavalla” -nimisessä Saarisen muotokuvassa Kurjensaari rakentaa kuvaa vasemmistolaisessa työläisperheessä kasvaneesta pojasta, joka sotien jälkeen siirtyy ammattiyhdistysliikkeen palvelukseen ja myöhemmin valitaan Suomen Kommunistisen puolueen puheenjohtajaksi, monia yhteiskunnallisia ja kansallisia vastakkainasetteluja ilmentävään asemaan. Vastakohtaisuuksien sijasta Kurjensaari kuitenkin korostaa Saarisen isänmaallisuutta. Muotokuvan päättävä kohtaus on Ramsaynrannasta, kesäiltana Saarisen purjeveneeltä:

Tehdessäni lähtöä Aarne Saarinen kehotti:

- Kävele sitä ulkolaitaa myöten, minä pysyn tällä puolella, että veneen tasapaino säilyy. Kun seuraavan kerran näin veneen, se ponnisteli navakassa lounaistuulessa ja perässä liehui virkeänä siniristilippu. (S, 274.)

Kahdella laidalla tasapainoilu veneen keinuttamisen välttämiseksi, yhteistyö ja liehuva siniristilippu ilmentävät Kurjensaaren näkemystä Saarisesta, mutta ennen kaikkea ne puhuvat Kurjensaaren itsensä puolesta. Kurjensaari näki muiden ihmisten kautta selvemmin myös omaan elämäänsä ja vakaumukseensa.

Kurjensaaren muotokuvaesseet kokoelmissa Veljeni merellä myrskyävällä, Kansankunnan kaapin päällä ja Silmätikut taiteilevat objektiivisuuteen pyrkivien Suomen yhteiskuntahistoriaa kronikoivien henkilöhistorioiden ja Kurjensaaren oman persoonan välillä. Muotokuvat toteuttavatkin esimerkillisesti Kurjensaaren omaa luonnehdintaa kirjoitustyylistään Taistelu Huomispäivästä -teoksen (1948) esipuheessa, jossa hän toteaa subjektiivisuuden olevan ihmisen kallein anti objektiivisuudelle (Kurjensaari 1948/1967, 7). Melankolisen sävynsä tähän luonnehdintaan tuo se, että siinä missä subjektiivisuus tarjosi vielä 1940-luvulla Kurjensaarelle astinlaudan yleisiin asioihin, yhteiskunnan objektiivisuuteen, oli siitä muotokuvien kirjoittamisen aikaan tullut taakka. Kurjensaari kirjoittaa päiväkirjassaan vuoden 1972 alussa, että muista ihmisistä kirjoittaminen toimi keinona päästä pois omasta itsestään, "epäonnistuneesta ihmisestä" (Kurjensaari 1973, 285). Tässä suhteessa muotokuvat merkitsivät Kurjensaarelle "itsemurhan myönteistä lajia”, luopumista itsestä muiden ihmisten nimissä. Samalla hänelle on varmasti ollut selvää, että itsemurhallaan - muotokuvien kirjoittamisella - hän jätti ennen kaikkea oman nimensä kirjojen kansiin ja aikalaistensa huulille. ${ }^{1}$

\section{Viitteet}

${ }^{1}$ Artikkelin kirjoittaja kiittää Koneen säätiötä, joka on rahoittanut kirjoittajan suomalaista esseistiikkaa kartoittanutta post doc -hanketta ”Esseet kriisissä”. 


\section{Kirjallisuus}

Boetcher Joeres, Ruth-Ellen \& Elizabeth Mittman (eds) 1993. Politics of the Essay. Feminist Perspective. Bloomington and Indianapolis: Indiana University Press.

Good, Graham 1988. The Observing Self. Rediscovering the Essay. London \& New York Routledge.

Kantola, Alli 1969. Aika taittuu ihmisessä. Savon Sanomat 9.11.1969.

Korhonen, Kuisma 1998. Essaying Friendship. Helsinki: Yliopistopaino.

Korhonen, Kuisma 2013. Esseistiikan uudet kuviot. Mika Hallila, Yrjö Hosiaisluoma, Sanna Karkulehto, Leena Kirstinä \& Jussi Ojajärvi (toim.), Suomen nykykirjallisuus 1. Helsinki: SKS, 304-314.

Kurjensaari, Matti 1948/1967. Taistelu huomispäivästä. Isänmaan opissa 1918-1948. Helsinki: Tammi.

Kurjensaari, Matti 1966. Veljeni merellä myrskyävällä [=VMM]. Muotokuvia muistista. Helsinki: Tammi.

Kurjensaari, Matti 1969. Kansakunnan kaapin päällä. Muotokuvia muistista [=KKP]. Helsinki: Tammi.

Kurjensaari, Matti 1971. Silmätikut. Muotokuvia muistista [=S]. Helsinki: Tammi.

Kurjensaari, Matti 1973. Syntynyt sivulliseksi. Näkyjä ja näkemyksiä 1960-1973. Helsinki: WSOY.

Laitinen, Kai 1967. Matti Kurjensaari - näkijä. Pohjolan Sanomat 12.10.1967.

Laitinen, Kai 1970. Sodasta rauhanvuosiin. Annamari Sarajas (toim.), Suomen kirjallisuus $V$. Helsinki: SKS ja Otava, 569-588.

Niiniluoto, Marja 1969. Kuka kukin tänään on. Helsingin Sanomat 12.10.1969.

Obaldia, Claire de 1995. The Essayistic Spirit. Literature, Modern Criticism, and the Essay. Oxford: Clarendon Press.

Riikonen, Hannu K. 1990. Mikä on essee? Helsinki: SKS.

Ripatti, Aku-Kimmo 1969. Suruksi käy. Kaleva 28.10.1969.

Sanders, Scott Russell 1991. Secrets of the Universe. Scenes from the Journey Home. Boston: Beacon Press.

Tallqvist, J. O. 1967. En Kulturkritiker bland människor. Hufvudstadsbladet 4.5.1967.

Tallqvist, J. O. 1971. Porträttmålaren Kurjensaari. Hufvudstadsbladet 1.10.1971.

Tarkka, Pekka 1971. Keskikenttä tukialueena Kurjensaaren maajoukkueessa. Helsingin Sanomat 3.10.1971. 


\section{Arkistolähteet}

Suomalaisen Kirjallisuuden Seuran Kirjallisuusarkisto

Matti Kurjensaaren arkisto.

Kansio nro 6, kotelo 29440.

Kansio nro 8, kotelo 29442-29443.

Matti Kurjensaaren kirjailijahaastattelu 1974. Haastattelijana Paavo Eini. Kian $1986044 a$. 